\title{
UM DOMÍNIO DO REALISMO NA FICÇÃO DE BERNARDO CARVALHO
}

Paulo César Silva de Oliveira é professor adjunto de Teoria Literária da Faculdade de Formação de Professores da UERJ e Doutor
em Poética pela Universidade Federal do Rio de Janeiro. É autor da obra Poética da distensão (2010) e organizador da coletânea Memória e identidade: ensaios (2011).

E-mail: paulo.centrorio@uol.com.br

\section{Resumo}

Este artigo investiga a ficção de Bernardo Carvalho This article investigates Bernardo Carvalho's a partir dos questionamentos acerca de um fiction from the viewpoint of the questions pressuposto "domínio do realismo" nas narrativas surrounding a possible "domain of realism" in contemporâneas. A questão da paratopia de autor é contemporary narratives. The concept of paratopy is o ponto de partida para a discussão do papel do the starting point to discuss the role of the writer in escritor no campo literário. A essas indagações, the literary field. Following these problems, we will acrescentaremos o problema das relações entre add a discussion on the relations between representação e realidade, história e ficção, a partir representation and reality; history and fiction, das leituras críticas de Luiz Costa Lima e Karl Erik supported by Luiz Costa Lima and Karl Erik Schollhammer, dentre outros.

Para o estudo da posição do autor no campo intelectual, a noção de paratopia estabelecida por Dominique Maingueneau é um modo de entrada estratégico nos entrelugares da ficção contemporânea. A ideia de paratopia nos permite divisar, para problematizar, um corpo de relações no interior do qual Maingueneau aponta duas atitudes dominantes nos estudos das relações entre texto e contexto: por um lado, o apelo à história literária, compreendendo a obra em sua relação com o tempo que representa e exprime e é por ele influenciada; e, por outro, a orientação estilística, que entende a obra como um universo fechado, embora sem negar as relações sociais instaladas no texto. A corrente estilística vive à espera do "dia em que os progressos realizados na inteligência do funcionamento dos textos permitirem relacioná-los com seu "entorno" (Maingueneau, 2001, p. IX). O histórico dessa "espera" sublinha todo um percurso metafísico-artístico que procurou e procura estabelecer as bases de uma relação entre realidade, realismo e representação.

No que diz respeito à representação, a modernidade nos legou, como um de seus problemas dominantes, a crise e os impasses da relação entre a cena da enunciação e os processos enunciativos. Neste sentindo, podemos falar em "tensões" no campo da representação, no qual os vocábulos "limite", "crise", "desconstrução" e correlatos passam, mais insistentemente, a rondar a criação artística, provocando a teoria a pensar sob que novas bases a questão histórica das vinculações entre obra e sociedade pode ser pensada. A indissociação entre história e literatura, homóloga à percepção dos vínculos entre textos literários e sociedade, continua a provocar, conforme bem observado por Maingueneau, novas definições acerca da relação entre os dois terrenos - o da história literária e o da análise estilística -, muito embora esses entrecruzamentos, nos últimos trinta anos, especialmente, tenham se revelado por demais porosos, especialmente no âmbito da crítica. 
A essas questões, nosso trabalho pretende ainda reconhecer na figura do escritor um elemento reflexivo central para as discussões que se travam, hoje, acerca da problemática do realismo, da representação, da história e da crítica. Não se trata, obviamente, do velho biografismo, mas do questionamento do papel do autor no campo intelectual, em que importa, aqui, verificar de que forma seu projeto criador e sua condição paratópica também determinam formas de composição do enunciado das obras e também, de certa forma, escolhas e possibilidades, condições de produção e inserção da obra no mercado e no ambiente cultural e histórico. Como objeto de nossas interrogações, elegemos o escritor Bernardo Carvalho e sua obra como fios condutores da reflexão que segue. Para isso, nos valeremos inicialmente das teorias do discurso pensadas por Maingueneau, e uma breve apropriação de suas noções deve servir de introdução ao debate proposto. Com ela, queremos perceber como a recepção das obras impulsiona o debate acerca das escolhas artísticas em um campo intelectual cujo diapasão crítico parece querer afinar as obras com uma suposta "demanda de realismo". Desse modo, é inevitável pensar a tensão entre o escritor, o campo literário e a sociedade da qual ele (faz) parte.

Com isso, a noção de paratopia insere no discurso acerca do realismo a presença e a pertinência do escritor, por vezes relegada a um plano secundário, ou mesmo rejeitada por certas correntes críticas. Anulado o velho biografismo, a paratopia do autor o surpreende em um campo literário dado para verificar até que ponto seus modos de inserção na tribo da qual participa ou a qual diz rejeitar revelam relações, ora tensas, ora apaziguadas, com os diversos elementos que compõem o campo literário, influenciando o processo de produção da obra e que nela podem ser verificados. Além disso, a noção de paratopia rejeita a velha sociologia, pois não se trata de estender mecanicamente os fenômenos relacionados à vida do autor e à produção da obra ao texto que é produzido. Avancemos um pouco mais no estudo dessas noções, cujos exemplos se disseminam nessa reflexão.

A pertinência de todo escritor no campo intelectual nunca é estável ou neutra e a condição de existência de todo autor está condicionada a essa impossibilidade "de se designar um 'lugar' verdadeiro" (Maingueneau, 2001, p. 27). Em relação aos perigos de se tratar essa questão, antepõem-se a vulgarização ou o desprestígio do escritor no campo intelectual, de um lado, e a tendência a fortalecer a imagem que os escritores criam de si mesmos, de outro. Para Maingueneau, sem "localização" não haverá instituições que legitimem as obras, mas ao mesmo tempo a literatura legítima demanda o que ele chama de "deslocalização", ou seja, essa negociação difícil que ocorre em uma "localidade paradoxal", na qual se instauram o lugar e o não-lugar. Maingueneau chama esse processo de paratopia. Em sua versão dicionarizada, o verbete paratopia designa "a relação paradoxal de inclusão/exclusão em um espaço social que implica o estatuto de locutor de um texto que decorre dos discursos constituintes" (Maingueneau \& Charaudeau, 2008, p. 368). Adiante, veremos que a noção ampliada se estende ao tecido mais amplo do corpo social: 
A paratopia não pode se reduzir a um estatuto sociológico; neste nível, há apenas paratopias potenciais: não basta ser exilado ou órfão para ser criador. Para que a paratopia interesse ao discurso, é necessário que seja estruturante e estruturada pela produção dos textos: enunciando, o locutor se esforça para superar seu impossível pertencimento, mas este impossível pertencimento, necessário para poder enunciar desse modo, é confortado pela própria enunciação (Maingueneau \& Charaudeau, 2008, p. 369).

Acrescentemos, à noção de paratopia, o papel dos receptores, lembrando que "a recepção das obras também faz parte dos componentes estruturais do campo intelectual e determinam relações, inclusive de poder e legitimação (Oliveira, 2011, p. 141). Portanto, no conjunto complexo e quase sempre problemático das negociações no campo literário, divisamos vários domínios que o autor necessariamente atravessa. Ao gerir sua posição no campo, os autores denunciam seu lugar de fala, por meio de um duplo jogo de atração e retração, de pertencimento e fuga. Daí discutir-se, hodiernamente, o alcance das noções de marginalidade e canonicidade, visto que também o ponto de vista de quem olha essas relações implicará seu posicionamento entre uma e outra. E aqui chegamos à questão mais cara à discussão que se travará aqui.

À problemática do realismo na ficção de hoje, instauram-se vários pressupostos críticos que expandem essa questão para áreas mais densamente povoadas. Sendo uma das formas de exercício de uma prática intelectual no campo literário, a criação artística não se dissocia do percurso biográfico de seus autores, nem de suas formas de relacionamento com o campo literário. Essas denunciam a própria condição dos escritores no exercício do ofício. A obra como fruto de uma enunciação inserida em um contexto determinado, mas que paradoxalmente também o determina, passa a significar a partir de certos embates e conflitos. As tensões do campo literário não são meras causalidades e sim fenômenos do processo que pressupõem uma dinâmica de atores e condições. À abordagem marxista tradicional, que incide apenas na noção de superestrutura ou na teoria do reflexo ideológico, a teoria do discurso propõe um reconhecimento, tanto dos efeitos da superestrutura quanto dos procedimentos ideológicos, porém a eles acresce noções de correspondência, trânsito, negociação. Assim, Maingueneau (2001, p. 46) precisa grafar biografia como bio/grafia, em que bios ruma à graphia, ao mesmo tempo em que escrita ruma à vida. Indissociável nessa relação é a posição de Bernardo Carvalho no campo literário. Conforme veremos, a noção de paratopia implicará necessariamente a confluência de questões que determinam o posicionamento do romancista frente aos impasses contemporâneos, dentre os quais elegemos o que chamaremos de "um domínio do realismo", para estendê-lo ao debate mais amplo e controverso sobre a compreensão das possibilidades do realismo na prosa atual.

O escritor, como elemento ativo no campo intelectual, conforme já disse Pierre Bourdieu (1968), também é afetado, ao mesmo tempo em que afeta o sistema de relações sociais em que a criação literária se realiza, e sua posição no campo e a forma como se relaciona com ele definem a situação paratópica, em seus graus e medidas. A fala do autor, recentemente ainda negligenciada por certas correntes teóricas 
predominantes a partir da segunda metade do século $\mathrm{XX}$, se mostra, no âmbito das teorias do discurso, como um elemento fundamental para se compreender as relações entre escrita literária e realismo. No caso da ficção contemporânea, a crise da representação, espelhada na obra de escritores diversos, revela um complexo de reflexões ambíguas, conflitantes, já que o próprio processo que vincula obra literária à noção de real é ele próprio bastante problemático.

Ao definir o que entende como o panorama da literatura hoje, Bernardo Carvalho (2011, p. 134) dirá que

(...) ou é expressão da experiência ou então é memória, diário, autobiografia. Ou quando é romance, é um tipo de literatura que toca direto no mais básico do humano, é o realismo que emociona, um realismo psicológico, dramático, com grande apelo sensibilizador. Não tem mais aquela história da literatura como um trabalho de mão dupla do leitor e do escritor, um trabalho intelectual; não tem mais isso.

Para Carvalho, qualquer desvio do realismo é desautorizado pelo consenso crítico, que prevê para a literatura que não promova o elogio do real uma espécie de cerebralismo frio, de experimentação aborrecida. À alternativa de uma literatura mais reflexiva como, por exemplo, a de Maurice Blanchot, Carvalho vê também um lado incômodo:

Você cria uma tal consciência da língua e da linguagem, que é impossível continuar produzindo, porque é como se você teorizasse tudo aquilo de tal maneira, que esgotasse a própria possibilidade de criação. Então tem esses dois lados. Por um lado, é interessante, porque essa tradição é uma alternativa a um mundo de consenso que está se formando e, por outro, eu reconheço que essa tradição de uma autorreflexão absoluta sobre a literatura é um beco sem saída (Carvalho, 2011, p. 135).

Entre essas duas colunas - a que constrói um consenso em torno da demanda de real a qual a literatura deve preencher e a que prevê um tipo de literatura autoconsciente, que transforma o texto na própria dinâmica reflexiva da linguagem - Carvalho percebe o percurso atual da história da literatura desaguando no realismo, ainda que complexo, como em Virginia Woolf e James Joyce. A vivacidade, a humanidade, a realidade dos personagens parecem suplantar os personagens-ideia, os personagens de papel. Dentre outras, permanece a questão do espaço da literatura e da forma como escritores podem ou devem agir nesse universo conturbado por duas inclinações que parecem irreconciliáveis: a demanda de realismo e a escrita autorreflexiva. A percepção de Carvalho pode ser ajustada ao que Karl Erik Schollhammer já apontara:

Carvalho cria enredos que têm a complexidade das narrativas policiais, em que os detetives são personagens à procura de uma compreensão de sua identidade e, com frequência, de sua origem familiar, como em alguns enredos do americano Paul Auster, nos quais os personagens circulam numa intensa atividade interpretativa, que eles mesmos redefinem para tentar entender os acontecimentos, lendo a vida como se lessem um livro (...). Obcecados pela tarefa de elaborar respostas, os personagens de Carvalho estão em movimento de investigação dos fatos e dos eventos que escreveram suas 
histórias e fornecem pistas que levam à origem familiar e à identidade, mas sempre numa construção de realidade realista apenas em aparência e que, no desenrolar dos eventos, vai perdendo a verossimilhança e congruência (2009, p. 34-35).

Nesse entrecruzamento de duas vozes, a do teórico-crítico e a do artista que ficcionaliza o domínio do realismo na produção ficcional de hoje, podemos estabelecer dois parâmetros de discussão que nos interessam nesse artigo.

Em primeiro lugar, se o consenso pretende estabelecer o realismo como uma exigência da ficção atual, seria lógico que uma literatura de "resistência" deva justamente caminhar na contramão dessa concepção; segundo, se a consciência extrema da língua e da linguagem na prosa autorreflexiva pode esgotar a possibilidade da criação, escapar a essa aporia não significa encontrar ou buscar saídas, apenas revela uma "atitude contestatória", que demite o consenso, mas a ele, de certa forma, recorre e depende. O próprio Carvalho (2011, p. 139) admite que talvez o problema esteja na "ideia de modelo" e não no realismo, já que seus próprios livros são bastante realistas. Ao perceber nessa "construção de realidade realista" apenas uma "aparência de realismo", Schollhammer (2009), de certa forma, aponta um caminho de análise a ser percorrido, embora não o desenvolva extensivamente em seu livro, pensado mais como uma apresentação da ficção contemporânea e não como uma reflexão particular de uma poética de autor. Entretanto, essa vereda se revela fértil para o que aqui queremos discutir.

$\mathrm{Na}$ entrevista a que constantemente aludiremos, Carvalho pontuará sua fala por uma repetida crítica ao que chama de "tendência ao elogio do realismo" (2011, p. 135). Sua análise se volta contra o dogmatismo que vem se constituindo em torno de uma ideia realista contra um suposto cerebralismo que é corroborada especialmente pela imponente crítica advinda do mundo anglo-saxão. Para Carvalho, falar de sentimentos e da experiência é o que há de mais imediato na prosa considerada mais representativa no mundo anglófono-saxônico. No estado atual da ficção, o domínio do realismo exacerba uma "literatura da experiência" a qual o autor pode perverter como fator de resistência. Como exemplo, o escritor nos conta um episódio ocorrido durante sua estadia em São Petersburgo, por conta de um projeto que enviou escritores a diversas cidades do mundo para escrever uma história de amor.

Ao sair à rua para visitar um cyber café e pesquisar na internet, Carvalho é abordado, na volta a seu apartamento, por três indivíduos que efetivamente tentaram roubá-lo. Após o evento, o escritor passou a desenvolver um sentimento de pânico das ruas, o qual, evidentemente, teria que superar. Esse sentimento se transformou na própria experimentação do medo, homólogo ao que seus personagens deveriam sentir e ao que a linguagem do romance teria que expressar. A essa demanda de realismo exigida pela obra, a experiência concreta do medo poderia ser "transposta" para a trama, mas o que Carvalho aponta é mais revelador do que isso:

O livro culminou uma espécie de método literário que eu tinha inventado para mim e que já vinha desde Nove noites. Esse método é o contrário de uma literatura da 
experiência, porque ele a perverte: crio uma experiência falsa, artificial, mas vivo essa experiência de verdade. Quer dizer, o medo que eu tive não é falso, eu morri de pavor, só que a situação era toda construída. Eu fui viver esse tipo de sentimento, para poder escrever esse livro. Ao mesmo tempo em que tenho essa reação contra a literatura da experiência, eu a fabrico. O tipo de literatura que eu vinha fazendo dependia da experiência, só que era uma experiência fabricada - ou alucinada (Carvalho, 2011, p. 145).

Essa "fabricação da experiência" é homóloga ao que Schollhammer apontara e a que discutiremos nesse trabalho, a fim de estruturarmos uma discussão em torno da poética de Carvalho, que provisoriamente aceitaremos, conforme Schollhammer, como "realismo aparente".

Na percepção de Carvalho acerca de si e de sua obra, o que move a literatura é o desejo de desafiar o consenso. Ao sucesso obtido com Nove noites (2002) e Mongólia (2003), adveio a má recepção a $O$ sol se põe em São Paulo (2007). Referindo-se a uma "devastadora" crítica na Alemanha a esse último, Carvalho nos conta que a falta de verossimilhança teria sido o ponto nodal da argumentação negativa. Os personagens seriam "de papel”, "uma coisa cerebral”, sem "identificação psicológica e emocional mais imediata", e o livro seria, ao fim, algo que visava apenas a "pensar a literatura", um "livro autorreflexivo" (Carvalho, 2011, p. 140). O que a princípio originou uma espécie de bloqueio criativo - os efeitos da crítica alemã - se transforma, na própria reflexão do autor, em sua entrevista, em torno das relações conflitantes do escritor no campo intelectual: querer ser reconhecido e ao mesmo tempo rejeitar o consenso; querer e recusar o literário.

Conforme Maingueneau (2001, p. 56), "não existe, portanto, gesto bio/gráfico cujo significado seja independente das reivindicações estéticas que fundamentam uma obra". Daí uma correlação entre os ritos de escrita e os ritos genéticos, de que trata Maingueneau. Aos ritos de escrita, “(...) esse trabalho sobre o texto (rascunhos, correções...), justapõem-se os ritos genéticos”, “(...) comportamentos diretamente mobilizados a serviço da criação" (Maingueneau, 2001, p. 48). Conforme antes apontara Pierre Bourdieu, e evidenciado na fala de Carvalho sobre a crítica à sua obra, o artista pode repudiar ou aceitar a máscara que lhe é tributada, entretanto:

O que quer que faça ou queira, o artista tem que enfrentar a definição social de sua obra, isto é, concretamente, os sucessos e os revezes conhecidos por ela, as interpretações que lhe foram dadas aqui não posso alterar, pois está no original citado dessa forma a representação social, quase sempre estereotipada e simplificadora, que o público de amadores possui a seu respeito. Em suma, possuído pela angústia de salvação, o autor está condenado a esperar na incerteza os sinais sempre ambíguos de uma eleição sempre em suspenso: ele pode viver o revés como um sinal de eleição, ou o sucesso muito rápido e estrondoso como uma ameaça de maldição (em referência a uma definição, historicamente datada, do artista consagrado ou maldito), ele deve, necessariamente reconhecer em seu projeto criador a verdade de seu projeto criador dada pela recepção social de sua obra, porque o reconhecimento dessa verdade está contido num projeto que é sempre projeto de ser reconhecido (Bourdieu, 1968, p. 114). 
Nesse caminho percorrido, vemos que a problemática do realismo está refletida nas condições de legitimação do discurso do autor, que passa pelas instâncias diversas dos actantes do campo intelectual, no qual está inserido o campo literário. Autor, crítica, leitores, todos colaboram para o que Bourdieu entende como projeto de reconhecimento do autor, em suas incertezas na espera por sinais, sempre ambíguos, de eleição. Entretanto, poderíamos acrescentar às análises de Maingueneau e Bourdieu algo que os pensadores não consideraram: o escritor, como "filho de seu filho", isto é, como aquele que é filho daquilo que cria, também está exposto às próprias condições de sua criação. Melhor dizendo, há uma condicionante não pressuposta, que é o acaso, os desvios de rota, conscientes ou por necessidade da vida ou do jogo da criação; sem contar o velho instinto de resistência à autoridade, elementos que dão ao escritor certa prevalência em relação à crítica: crítica é o que vem sempre a posteriori. A crítica ou a análise do cientista social é sempre um olhar voltado ao passado, às experiências e vestígios acumulados no tempo, na história, e passa pela visão subjetiva do analista.

A experiência do escritor se dá no risco da produção, da ação e reflexão, sendo o próprio escritor construído por aquilo que produz. Portanto, seu caminho é sempre o de certa solidão, não apenas necessária, mas pré-condicionada pelo processo criativo. Não se trata de resgatar a condição especial dada aos artistas pelo Romantismo, mas de reconhecer um fator de prevalência do artista na singularidade de sua inserção e da inserção de sua obra no campo intelectual e literário como uma aventura quase sempre solitária e muitas vezes regida também pelo acaso, como no relato de Bernardo Carvalho. Ao assalto, sucedeu-se a descoberta de um método; ao medo sucederam-se as condições de criação de uma atmosfera de opressão que circulará por todo o romance $O$ filho da mãe (2009).

Deste modo, percebemos que o autor, ao receber a crítica como um corpo estranho àquilo que, em sua vivência, foi experimentado de forma diversa, apenas expõe as contradições e complexidades do campo literário. As possibilidades da crítica sempre esbarram nesse, por vezes, conflituoso universo da autoria. As análises críticas, as palavras do crítico promovem, renovam, recortam todo o ambiente em que se constitui e legitima autor e obra, mas o imponderável que determina certos posicionamentos dos autores encontra como contrapartida a história, cuja dinâmica sempre pressupõe uma recuperação e reavaliação dos fatos.

A demanda de realismo só poder ser, hoje, concebida, quando contemplamos a efetiva participação do autor como elemento que possui voz no campo literário e que a usa, seja voluntariamente ou quando provocado a dar "respostas" aos questionamentos da órbita crítico-cultural sobre seu produto. Essa resposta, voltando à recepção da crítica alemã a $O$ sol se põe em São Paulo, insere no circuito não apenas a reação do escritor a pouca oferta de realismo apontada na revisão crítica de sua obra, mas também uma concepção poética de obra. Essa estruturação vai se efetivando, primeiramente, na rejeição de Carvalho ao sucesso dos romances Nove noites e Mongólia; e, em segundo lugar, na inverossimilhança buscada em $O$ sol se põe em São Paulo. Avancemos um pouco mais nessas questões. 
Em Nove noites e Mongólia, a representação do real se apresentava de forma peculiar e muito similar. O recurso a tipos de letra como marcas textuais que orientavam os leitores e estabeleciam as diferenças entre os textos; a relação entre a narrativa epistolar e o documento; o mistério da busca por uma identidade/verdade de forma detetivesca; a relação passado/presente; as fotos de capa e as fotos internas, relacionadas a experiências autobiográficas do autor; uma obsessiva referência a instituições, locais, pesquisas de arquivos, notícias de jornal; e a criação de uma linguagem que flertava e subvertia o realismo aparente. Invenção e história, ficcionalização e busca de uma relação de proximidade com os fatos; o fato e sua subversão, tudo convergia para que uma parcela da crítica estabelecesse nas duas obras uma relação de complementaridade entre realismo e reflexão; criação e representação social. Mas se estendermos essa análise a $O$ sol se põe em São Paulo, não encontraríamos ali a mesma busca, com efeitos e resultados semelhantes? De certa forma, sim, mas o que podemos inferir da leitura da obra é que, na construção narrativa de $O$ sol se põe em São Paulo, Bernardo Carvalho procurou afirmar um desejo de revelar o real no abrigo do disfarce. Ou seja, a trama detetivesca se amolda a certo percurso da contemporaneidade, que visa conduzir o enigma para o centro da narrativa, entretanto fazendo do próprio enigma, e não dos elementos verossimilhantes que lhe dão forma, o ponto nodal da obra. Neste romance, o exercício da linguagem autorreflexiva, o jogo intra e extratextual, a recuperação histórica que no fundo falsifica a história, o apelo reflexivo em torno da impossibilidade da ideia de verdade formam o verdadeiro arcabouço ficcional da obra: "Fiz um livro totalmente artificial, tudo é mentira, tudo é de papel, tudo é falso. Acabei pagando" (Carvalho, 2011, p. 148). Ao risco de pautar sua narrativa na recusa da verossimilhança, o preço pago foi o da demolição crítica. Mas como se estrutura esse romance enigmático? O que norteou a crítica alemã em sua ácida recusa do romance realmente reflete as escolhas do autor?

Em uma leitura bastante particular de $O$ sol se põe em São Paulo, e para nos socorrermos da força do exemplo, faremos um apanhado de uma série de camadas narrativas sobrepostas, que ora se equivalem e ora se alternam, em movimentos nãoregulares. Podemos observar uma narrativa primária (1), em que o narrador ficcionaliza o fracasso dos (seus) sonhos; uma narrativa secundária (2), na qual o enunciado gira em torno da história desse narrador-personagem e de seu fracasso; uma terceira camada narrativa (3) dará conta de um relato futuro, que ainda não se apresenta para o leitor, que junto com esse relato futuro poderá reconhecer os insights que dele decorrem; uma quarta camada narrativa (4), a história narrada pela japonesa, e que chamamos de "a história em si”, no nível das ações, ou seja, do enunciado; uma quinta camada (5), a qual trataria do que se esconde por detrás da história narrada e que impediria o estabelecimento de uma verdade ou de um sentido acabado para os acontecimentos no âmbito da representação do real; uma sexta camada (6), a da história que será repassada, enviada a outrem - no caso, um personagem identificado como "o homem com o lábio leporino" - e, por fim, uma espécie de ultra-narrativa, uma camada (7) que se estabelece 
na representação do mundo sensível e que se estende à reflexão moral, à crítica aos elementos díspares, contraditórios, dispersos naquelas sociedades representadas.

Cada uma dessas camadas dialoga entre si, indicam um modo de leitura, mas não são estruturadas de forma ordenada, como um conjunto orgânico e organizado, e sim como uma espécie de costura indisciplinada a requerer do leitor-modelo a compreensão de que a representação do real, ao fim, se dá na própria estruturação dessa indisciplinada costura narrativa". Nesse sentido, a crítica alemã acerta quando mostra que o alvo da obra é a discussão acerca do poder e alcance da literatura e de sua possibilidade como linguagem, reflexão e autorreflexão. O equívoco da crítica alemã, por outro lado, talvez seja o de partir desse mesmo princípio norteador para daí condenar a obra por ser eficiente naquilo que ela se propõe fazer, ou seja, criar uma atmosfera de antirrealismo, conforme o próprio paratexto da epígrafe já apontara: “[...] estranhos discursos, que parecem feitos por um personagem distinto daquele que os diz e dirigir-se a outro, distinto daquele que os escuta" (Valéry, Paul, apud Carvalho, 2007, p. 7).

Assim, aquilo de que Carvalho se ressente, talvez esteja mais bem localizado na predisposição de certa modalidade ou tendência da crítica em supor que a única forma de se estabelecer uma construção literária válida entre arte e representação social,ou entre história e ficção, seja possível ou desejável somente no chamado realismo tout court e em sua expressão mais antiga na tradição ocidental: a busca eficiente pela verossimilhança. No fundo, o debate que retorna é o das velhas categorias platônicoaristotélicas, em sua eterna fricção entre os poderes da história, da ficção, da representação e de seus efeitos na relação com o real. O realismo, seja em uma ou em outra acepção, sempre volta como debate crítico, como forma de reconhecimento das relações entre arte e mundo, muitas vezes como questão recalcada.

$\mathrm{Na}$ crítica alemã a $O$ sol se põe em São Paulo, a despeito de critérios de valor nela envolvidos, destacamos que, se o diverso e o irregular possuem uma ordem e entram nas narrativas segundo certas escolhas, o princípio da verossimilhança - no caso, a falta dele - como desqualificação do material literário revela o que Carvalho chama de "consenso do realismo": uma lei geral para a criação literária. Na medida em que Carvalho rejeita essa lei geral mas, ao mesmo tempo, por ela é atraído, seja por meio de um jogo paranoico, em que a realidade histórica se impõe - como no romance Nove noites - ou por conta de uma irrealidade construída, obsessivamente buscada, em $O$ sol se põe em São Paulo, podemos dizer, então, que a tensão entre arte e realismo, entre arte e realidade se configurame como problemática central na obra de Carvalho, desde Onze: uma história.

Não poderíamos esquecer que, dentro dessa relação, algumas escolhas, como o tema da nação fazem parte dessa incessante compreensão dos limites e alcances do realismo. Acoplada à ideia de nação, não há como esquecer que, nos romances de Carvalho, há uma recusa radical da ideia de identidade nacional - a esta, o escritor atribui um caráter fascista -, cujo ponto de inflexão se deu no período da ditadura militar, desde 1964. Sua escrita se afasta da atração identitária que permeia nossa 
história literária de forma bastante clara e quase programática, e se revela por conta de sua prosa de recusa do realismo, a rejeitar também o conforto e o bem-estar embutidos na ideia de nação como expressão das fulgurações de identidade: “(...) o lugar da verdade não está na identidade, mas fora dela, na quebra dessa identidade" (Carvalho, 2011, p. 156). Assim, podenos ver que, a partir de Onze: uma história, os indivíduos ficcionalizados se mostram dispersos em um único lugar: o mundo. A atração por esse mundo de fronteiras que deverão ser transpostas é, portanto, o motivo ideal para a representação da perambulação e da procura incessante pelo desconhecido, pelo mistério, que, ao final, é o próprio mistério da identidade. Neste mundo fronteiriço e semovente, os diversos sujeitos, vindo ou indo de/a locais distantes da nação a que conflituosamente pertencem, são representados e representam o que entendemos como "odisseia rumo a uma identidade jamais encontrada ou recuperada".

Como alguns exemplos, em Mongólia, acompanhamos a busca por um sujeito que se perde na solidão e na aridez do território oriental. Já em Nove noites, retraçamos o périplo do antropólogo - indivíduo diaspórico por excelência, investigador das identidades e diferenças, mas ele mesmo a "exceção" no seio das culturas por que transita - pelas tribos africanas e, no Brasil, pela tribo dos krahô. O Japão e a cidade de São Paulo, reinventados, por onde perambulam os personagens de $O$ sol se põe em São Paulo, requer dos leitores uma reavaliação dos limites do realismo. Por fim, na Tchetchênia e na São Petersburgo de $O$ filho da mãe, por onde dois jovens se encontram e se perdem, podemos encerrar esse breve percurso por fronteiras porosas, que certamente ainda serão objetos de obras posteriores de Carvalho.

Em todas as obras citadas, e sob qualquer hipótese acerca do conjunto das narrativas de Carvalho, não há como se descartar a atração de sua prosa pelo realismo. Seja na pesquisa ostensiva do espaço, na riqueza do detalhe, a mathesis ali se revela, muito embora o realismo de Carvalho, considerado sob outro viés, rejeite a identificação com o real fundado em certos idealismos, a recordar: a noção de identidade; o ideal de nação; o elogio do lugar de origem, a recusa em associar sua prosa a um projeto nacional ou de grupo, a incessante desconstrução desses processos identitários de construção de nação, ou a opção pelo trânsito, pela instabilidade.

Promovendo fissuras lá onde o fascismo da identidade encobre um mundo de desastres que se esconde no guarda-chuva das fronteiras, a literatura de Carvalho revela ainda que retorna como questão a função do intelectual público e seu papel diante de um mundo no qual se desreprime a demanda de real, após o 11 de setembro, a guerra do Iraque, a era Bush e a emergência de novos atores no cenário do capital globalizado, conforme M. A. Rafey Habib:

One of the consequences of the Iraq War is that it has forced us to rethink the nature of our own democracy, of its workings and the complex levels which constitute it: not only a certain system of political parties and voting, but the nature of the media, the education system, access to reliable information and the possibility of public participation. The knowledge and ability to make informed decisions is a crucial component of the democratic process; and the critical foundations of such knowledge 
lie in the humanities, in a knowledge of history, of religion, of political systems, and, above all, the ability to think and read critically (Habib, 2008, p. 204). ${ }^{1}$

Esse caráter e essa atitude de reflexão acerca de uma visão de mundo e das possibilidades do posicionamento público dos leitores-críticos na compreensão de questões contemporâneas, em que a ideia de nação sobressai, requerem também da crítica uma tomada de posição quanto às relações entre representação e realidade. Isso pode ser um modo de entrada na discussão crítica da obra de Carvalho. Luiz Costa Lima, sob aspecto um tanto diverso, mas que de certa forma dialoga com o que afirmamos, diz que Bernardo Carvalho confia as ambiguidades que elabora em sua prosa a um leitor sensível - o qual, obviamente, o romancista não pode pressupor, obviamente - atraído pela "acessibilidade" de sua obra. É esse leitor que terá a tarefa de refletir sobre os modos "como o autor procura responder à situação contemporânea da prosa ficcional" (Lima, 2002, p. 274).

Em sua análise de Teatro (1998), Lima nos mostra que o falso se instaura na própria realidade ficcionalizada, o que torna problemático o referencial. Esse é um dilema ao qual a teoria deve se voltar: “(...) para que se revele como doença da linguagem, o texto literário há de diminuir suas concessões ao leitor, isto é, não pode conceder que ele a receba como divertimento" (Lima, 2002, p. 275). Então, a tensão se instaura entre um texto que oscila entre o acesso do grande público, ao optar pela trama detetivesca, e por uma atração do real, no mesmo movimento em que concede pouco ao leitor, requerendo dele um esforço que, paradoxalmente, pode afastá-lo. A isso, acresce o que Lima chama de "falha" do escritor: "Ela parece estar na busca extremada de transformar o inverossímil em verossímil; em não deixar brechas para uma leitura diversa" (Lima, 2002, p. 276). Deste modo, ao eleger a ambiguidade como fator de satisfação do leitor mais exigente, ela não demitiria, por outro lado, o leitor mais interessado no divertimento. Sanar essa brecha, à época, seria o caminho a percorrer para que Carvalho se tornasse o grande escritor que prometia ser.

Nesse ponto, tracemos um paralelo entre a crítica de Lima e a recepção da crítica alemã. À inverossimilhança buscada, e que determinou um esvaziamento do realismo, a crítica alemã via um defeito. Lima, por outro lado, entende que, em Teatro, ao explicar e justificar as ações, Carvalho torna evidentes seu caráter de inventadas, o que denotaria uma ficção calculada. As duas interpretações revelam sutis proximidades e afastamentos. Enquanto, para a crítica alemã, estruturar-se como puro fingimento seria uma falha, por elevar a tema do romance $O$ sol se põe em São Paulo a própria ficção e não o real representado, Lima (2002, p. 276) aceita a interpretação de Wolfgang Iser, de que a ficção se distingue do não-ficcional por se revelar como fingimento. Não é aí que residiria a "falha" de Teatro, mas sim no desnudamento do processo, que não deixa espaço para passeios inferenciais do leitor.

Falha corrigida em As iniciais (1999), Carvalho iria revelar, naquele romance, uma "ficcionalidade que, ao se perverter, controla o impulso questionante da própria ficção" (Lima, 2002, p. 282). Equilibrar-se nesse jogo entre realismo e autorreferencialidade, para uma crítica e para a outra, nos parece ser então o argumento 
central dessas reflexões teóricas. Em ambas, revelam-se os estatutos ideológicos dos críticos e suas reações se mostram, conforme Terry Eagleton, ligadas a crenças mais gerais, pois "não há reação crítica que não tenha mais ligações, e, assim sendo, não há nada que se assemelhe a um julgamento ou interpretação crítica puramente 'literária"” (1983, p. 16).

$\mathrm{Na}$ trajetória artística de Carvalho, percebemos - à exceção do episódio da recepção a $O$ sol se põe em São Paulo - sua atração por um estado permanente de invenção que configura uma literatura do entre-lugar. Embora fronteiriça e formalizada na procura do diálogo cada vez mais intenso com um público-leitor ávido de realismo, ela exige, contraditoriamente, desse público, que reverta suas expectativas para que possa transitar no universo ficcional, entendendo-o como uma máquina de fabricar experiências.

Para um possível desfecho de nossa intervenção, retomaremos brevemente a leitura do romance Nove noites com base em algumas colocações de Karl Erik Schollhammer, que, dadas as limitações de espaço, serão futuramente desenvolvidas com mais propriedade.

Por ora, será suficiente dizer que o realismo de um romance como Nove noites deriva, em primeiro lugar, desse lócus não-localizável, dessa impossibilidade de a literatura fazer "aparecer" o real, de mimetizá-lo a ponto de, com ele, confundir-se. Tal processo só pode, ao final, revelar os modos e funcionamentos da linguagem, uma espécie de efeito de atração e repulsa. As cartas recebidas e enviadas por Buell Quain a Claude Lévi-Strauss, Heloísa Alberto Torres e a tantos, dentre a ostensiva documentação com que deparamos, formam uma espécie de inventário ficcional do fato histórico, um tipo de biografia em que o possível media relações entre representação e realidade, mostrando que avançamos pouco desde Aristóteles. Mas a originalidade da arte literária se insinua na possibilidade de reconduzir o antigo problema por caminhos diversos.

Ao final de sua leitura, o leitor de Nove noites encontrará, no mosaico de possibilidades, caminhos para discutir o efeito de miragem e a validade do realismo em uma época na qual o relato metaficcional convida a historiografia a um passeio inferencial, no qual "o presente contemporâneo é a quebra da coluna vertebral da história e já não pode oferecer nem repouso nem reconciliação" (Schollhammer, 2009, p. 12. Daí que "a história não está escrita como ocorreu, mas está ocorrendo meticulosamente como se fosse escrita" (Schollhammer, 2009, p. 143). Concluindo, Schollhammer dirá que

(...) o novo realismo se expressa pela vontade de relacionar a literatura e a arte com a realidade social e cultural da qual emerge, incorporando essa realidade esteticamente dentro da obra e situando a própria produção artística como transformadora. Estamos falando de um tipo de realismo que conjuga as ambições de ser "referencial", sem necessariamente ser representativo, e ser, simultaneamente "engajado", sem necessariamente subscrever nenhum programa político ou pretender transmitir de forma coercitiva conteúdos ideológicos prévios $(2009$, p. 54). 
O engajamento não-panfletário e a recusa de um caráter representativo talvez possam ser dois elementos dominantes naquilo que Schollhammer chamou de "novo realismo", ou de "realismo de novo". Acrescentaremos, para deixar em aberto o debate, uma frase do escritor americano David Leavitt sobre a posição do escritor contemporâneo no campo literário: "Writers often disguise their lives as fiction. The thing they almost never do is disguise fiction as their lives" (Leavitt, 1999, p. 72) ${ }^{2}$ Talvez nesse entre-lugar possamos melhor estabelecer alguns novos modos de compreensão do realismo na prosa de Carvalho, reconhecendo que toda sistematização esbarrará sempre nas aporias, no improvável, no acaso, o que pode ser chamado de condição paratópica do autor, ela própria condição da escrita em um mundo no qual a impossibilidade da literatura provoca, em contrapartida, o movimento que a gera e consagra.

\footnotetext{
${ }^{1}$ Uma das consequências da Guerra do Iraque é que ela nos tem forçado a repensar a natureza de nossa própria democracia, de seus funcionamentos e dos níveis complexos que a constituem: não somente certo sistema de partidos políticos e de voto, mas a natureza da mídia, o sistema educacional, acesso à informação confiável, bem como a possibilidade de participação pública. O conhecimento e a habilidade de tomar decisões confiáveis é um componente crucial do processo democrático e as fundações críticas de tal conhecimento se estabelecem nas humanidades, em um conhecimento da história, da religião, dos sistemas políticos e, acima de tudo, da habilidade de pensar e ler criticamente [Nossa tradução].

2 "Os escritores sempre disfarçam suas vidas como ficção; o que quase nunca fazem é disfarçar a ficção em suas vidas" [Nossa tradução].
}

\section{Referências Bibliográficas}

BOURDIEU, Pierre. Campo intelectual e projeto criador. In: POUILLON, Jean (Org.). Problemas do estruturalismo. Rio de Janeiro: Zahar Editores, 1968, p. 105-145.

CARVALHO, Bernardo. Onze: uma história. São Paulo: Companhia das Letras, 1995.

Teatro. São Paulo: Companhia das Letras, 1998.

As iniciais. São Paulo: Companhia das Letras, 1999.

Nove noites. São Paulo: Companhia das Letras, 2002.

. Mongólia. São Paulo: Companhia das Letras, 2003.

. O sol se põe em São Paulo. São Paulo: Companhia das Letras, 2007.

. O filho da mãe. São Paulo: Companhia das Letras, 2009.

Uma experiência fabricada. In: Lugar: Revista da Escola Freudiana. Rio de Janeiro: 7 Letras, 2011, p. 133-160. 
CHARAUDEAU, Patrick; MAINGUENEAU, Dominique. Dicionário de análise do discurso. São Paulo: Contexto, 2008.

HABIB, M. A. Rafey. Modern literary criticism and theory. Malden, USA; Oxford, UK; Victoria, AUS: Blackwell Publishing, 2008, p. 208-224.

LEAVITT, David. The term paper artist. In: . Arkansas. London: Abacus, 1999, p. $1-73$.

LIMA, Luiz Costa. Intervenções. São Paulo: Editora da Universidade de São Paulo, 2002. 1989.

A aguarrás do tempo: estudos sobre a narrativa. Rio de Janeiro: Rocco,

MAIGUENEAU, Dominique. O contexto da obra literária: enunciação, escritor, sociedade. 2. ed. São Paulo: Martins Fontes, 2001.

SCHOLLHAMMER, Karl Erik. Ficção brasileira contemporânea. Rio de Janeiro: Civilização Brasileira, 2009.

WINDELBAND, Wilhelm. A history of philosophy: v. 1. New York: Harper \& Row Publishers, 1958. 